\title{
Reactividad y expansión de las escorias de acería de horno de arco eléctrico en relación con sus aplicaciones en la construcción
}

\author{
Reactivity and expansion of electric arc furnace slag in their \\ application in construction
}

E.VÀZQUEZRAMONICH, M. BARRA
Univ. Politécnica de Cataluña

Fecha de recepción: 22-VIII-2001

ESPAÑA

\begin{abstract}
RESUMEN
La escoria de acero de horno de arco eléctrico presenta propiedades técnicas adecuadas para su uso como árido. El contenido de $\mathrm{MgO}$ es el principal causante de expansiones que afectan de forma distinta en función de la rigidez del sistema en que están integradas. Muestran una hidraulicidad que se traduce en formación de CSH, un silico aluminato cálcico y materia amorfa que pueden actuar como aglomerante débil, aumentando la resistencia de hormigones que las contienen. Ni los ensayos de Le Chatelier y autoclave convencionales, ni el llamado "steam test" (UNE-EN 1744-1) sirven para medir el potencial expansivo de las escorias cuando se encuentra en una matriz rígida. Se proponen nuevos métodos de medir el potencial de expansión de las escorias.
\end{abstract}

\section{SUMMARY}

EAF-slag have adequate technical properties for its use as aggregates. The $\mathrm{MgO}$ content is the main responsable of the expansions. The expansion produced affect in different way the new material depending of the rigidity of the matrices formed. EAF-slag shows hidraulicity and forms as reaction products $\mathrm{CSH}$, calcium aluminiunsilicates and amorphous phases that can increase the strength of concretes containing slags. The Le Chatelier, autoclave expansion and volume expansion tests can not be used in detecting the potential expansion of slag when used as aggregate in rigid matrix (concrete). Two new methods of measuring the potential expansion of EAF-slag are proposed.

\section{INTRODUCCIÓN}

En Europa se producen al año 12 millones de toneladas de escoria de acería, el $65 \%$ de las cuales encuentra una aplicación. La necesidad de garantizar un uso prudente de los recursos naturales, compaginando con el ahorro, de una parte, y de la otra la necesidad de disminución de los vertidos industriales, impulsa la utilización de residuos y subproductos como materiales de la construcción.

Las escorias de acería del proceso de arco eléctrico contienen esencialmente hierro, sílice y calcio $(25-40 \%$

\section{INTRODUCTION}

In Europe every year 12 million tons of steel slag are produced. $65 \%$ of the produced slag are used. The need to guarantee a cautious use of the natural resources and the need to decrease the dumping practices, further the use of industrial waste materials or co-products as building materials.

The electric arc furnace slag (EAF-slag) contain mainly iron, silicon and calcium $\left(25-40 \% \mathrm{Fe}_{2} \mathrm{O}_{3}\right.$, 
$\mathrm{Fe}_{2} \mathrm{O}_{3}, 10-17 \% \mathrm{SiO}_{2}, 25-40 \% \mathrm{CaO}$ ) y presentan unas propiedades técnicas muy adecuadas para su uso como áridos. El contenido de $\mathrm{CaO}$ y $\mathrm{MgO}$ libres es el causante de una posible inestabilidad volumétrica. Son frecuentes las escorias del tipo citado en las que la cuestión queda reducida al contenido de $\mathrm{MgO}$, que puede ser mayor que en otros tipos debido a las reacciones con el refractario. El tema ha sido discutido a nivel europeo en el "Task Group 8, TC 154

Aggregates" que finalmente ha aceptado esencialmente la experiencia alemana incorporando para ensayar la estabilidad volumétrica el llamado "steam test", ensayo de vapor que aparece en la norma UNE-EN 1744-1(3) publicada por CEN en 1998.

Existe un notable interés en varios países en ampliar el campo de aplicación de estas escorias más allá del ámbito de las capas no ligadas y de las de rodaduras con aglomerados bituminosos. Nos referimos a una posible aplicación en matrices de distintos contenidos de cemento, incluyendo los hormigones. Estas aplicaciones requieren una revisión de la reactividad posible de las escorias de acería de arco eléctrico y de la expansividad potencial que presentan los óxidos libres, además del análisis de la validez de los métodos actuales de ensayo en situaciones distintas a las que cubre el "steam test".

\section{OBJETIVOS DEL ESTUDIO}

Partiendo de la escoria de acero de arco eléctrico producida en Cataluña por la empresa CELSA, que presenta un bajo contenido de cal libre y un contenido de magnesio total que rara vez supera el $5 \%$, pretęndemos:

-Analizar su reactividad con el agua y sus consecuencias para posibles aplicaciones.

- Comprobar la eficacia de los métodos convencionales de ensayo del potencial expansivo.

-Estudiar una nueva metodología para determinar los efectos de la expansividad de las escorias de acero de arco eléctrico en su aplicación como áridos en matrices rígidas con cemento.

-Analizar la evolución química y microestructural que se producen en la realidad y en los ensayos, para concluir sobre su validez y aplicación general a este tipo de escoria.

\section{COMPOSICIÓN QUÍMICA Y MINERALÓGICA DE LAS ESCORIAS DE ACERÍA}

Se determinó la composición química y mineralógica de once muestras distintas de la escoria objeto de este trabajo. Las técnicas utilizadas fueron la fluorescencia de rayos $\mathrm{X}$ y la difracción de rayos $\mathrm{X}$ respectivamente. En la
$10-17 \% \mathrm{SiO}_{2}, 25-40 \% \mathrm{CaO}$ ) and has adequate technical properties for its use as aggregates. The content in free $\mathrm{CaO}$ and $\mathrm{MgO}$ is the cause of potential volume changes. In many EAF-slag the problem is reduced to the content of $\mathrm{MgO}$. The question has been discussed on the European level by the Task Group 8, TC 154 Aggregates, that finally has accepted essentially the German experience, incorporating the steam test as test method for slag, as a part of the UNE-EN 1744-1(3) published officially by CEN in 1998.

There is a growing interest in many countries in a larger use of steel slag, specially in matrices with different cement contents, including concrete. These application necessitate a revision of the possible reactivity of the EAF-slag and of the validity of the expansion tests in other conditions as the covered by the steam test.

\section{OBJECTIVES OF THE STUDY}

In the study of the EAF-slag produced by CELSA in Catalonia, that presents a very low free $\mathrm{CaO}$ content and a total magnesium content only occasionally over 5\%, we will:

-Analyse its reactivity with water and the consequences of the reactions for the applications. -Check the efficacy of conventional methods in the determination of the potential expansion.

-Study a new methodology to determine the effects of the EAF-slag expansivity in their application as aggregates in rigid matrices with cement. -Analyse the evolution of chemical and microstructural changes in the natural and in the test conditions, to check the validity and application of the test to the AEF-slag.

\section{CHEMICAL AND MINERALOGICAL COMPOSITION OF THE STEEL SLAG}

The chemical and mineralogical composition of the slag studied were determined in 11 different samples. The instrumental methods for this determination were $X$ ray diffraction. Table 1 
tabla 1 se presentan los principales constituyentes y su campo de variación en las muestras ensayadas. En la tabla 2 se presentan los principales compuestos cristalinos.

En la tabla 3 pueden verse los contenidos de cal libre $(\mathrm{CaO})$ determinado según la norma UNE 80-216-86 (4) presents the ranges of the composition in oxides obtained and the table 2 the main crystalline compounds.

In table 3 we can see the contents of free lime ( $\mathrm{CaO})$ determined by UNE 80-216-86 (4) and total

TABLA $1 / T A B L E 1$

Intervalo de variación de la composición química, expresada en óxidos, de las escorias estudiadas, elementos mayoritarios $\%>1 \%$

(Chemical composition in oxides, of the AEF slags studied, majority elements \% > 1\%)

\begin{tabular}{|c|c|c|c|c|c|c||}
\hline $\mathrm{Fe}_{2} \mathrm{O}_{3}$ & $\mathrm{CaO}$ & $\mathrm{SiO}_{2}$ & $\mathrm{Al}_{1} \mathrm{O}_{3}$ & $\mathrm{MgO}$ & $\mathrm{MnO}$ & $\mathrm{Cr}_{2} \mathrm{O}_{3}$ \\
\hline $32-46 \%$ & $25-33 \%$ & $10-16 \%$ & $5-10 \%$ & $3,3-6,4 \%$ & $2-6,5 \%$ & $1-2,5 \%$ \\
\hline
\end{tabular}

TABLA $2 / T A B L E 2$

Constituyentes cristalinos detectados por difracción de rayos $\mathrm{X}$ (Mineralogical compounds detected by XRD)

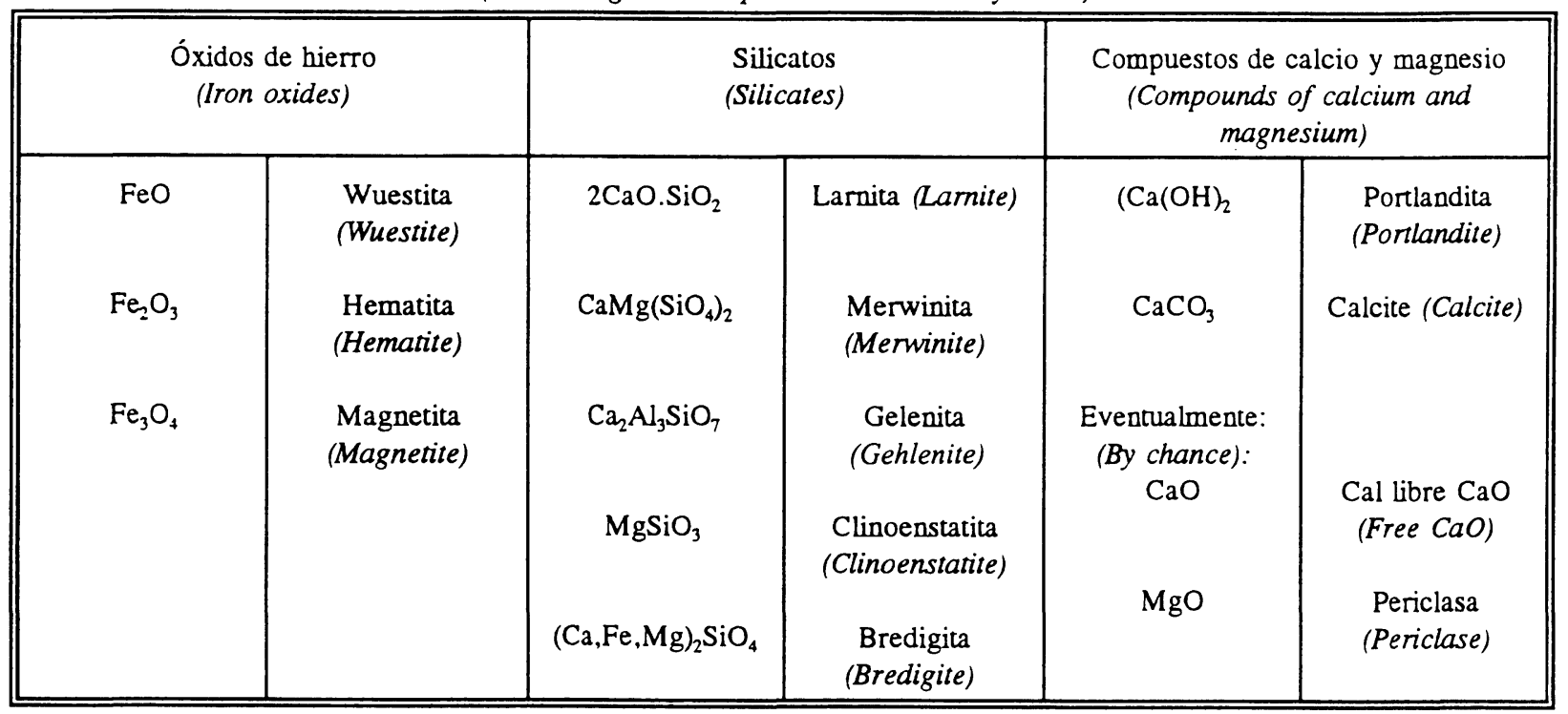

TABLA $3 / T A B L E 3$

Contenidos de cal libre $(\mathrm{CaO})$ y de magnesio total

(Contents of free lime ( $\mathrm{CaO}$ ) and total magnesium)

\begin{tabular}{||c|c|c|c|c|c|c|c|c|c|c|c||}
\hline $\begin{array}{l}\text { Escoria } \\
\text { (Slag) }\end{array}$ & 1 & 2 & 3 & 4 & 5 & 6 & 7 & 8 & 9 & 10 & 11 \\
\hline $\begin{array}{l}\mathrm{CaO} \\
(\%) \\
\mathrm{Mg} \\
(\%) \\
\begin{array}{l}\mathrm{MgO} \\
(\mathrm{DRX})\end{array}\end{array}$ & 0,08 & 0,07 & 0,09 & 0,09 & 0,11 & 0,15 & 0,14 & 0,08 & 0,08 & 0,18 & 0,11 \\
\hline
\end{tabular}

$\mathrm{D}=$ detectado por difracción de rayos $\mathrm{X}(D=$ detected by $X R D)$ 
y el contenido de magnesio total determinado por fluorescencia de rayos $X$. Se añade la presencia o no de periclasa $(\mathrm{MgO})$ detectada por difracción de rayos $\mathrm{X}$.

El magnesio puede estar presente en forma de cristales de clinoenstatita $\left(\mathrm{MgSiO}_{3}\right)$, merwinita $\left(\mathrm{Ca} 3 \mathrm{Mg}\left(\mathrm{SiO}_{4}\right)_{2}\right)$, también en la fase amorfa y, finalmente, como periclasa. Esta ultima es inestable en presencia de agua y genera brucita $\left(\mathrm{Mg}(\mathrm{OH})_{2}\right)$. Considerando las composiciones químicas y mineralógicas de cada una de las muestras de escoria ensayadas podemos afirmar que no existe relación entre el contenido de magnesio y la certeza de detectar periclasa por difracción de rayos $\mathrm{X}$ a estos niveles de cantidad de la misma.

El análisis semi cuantitativo de fase amorfa realizado mediante el programa Fullprof(Rodriguez-Carvajal, 1990) basado en el método de Rietveld, determina contenido de materia amorfa del orden de $70 \%$. La cuantificación obtenida no es un resultado exacto dada la complejidad de la matriz. Se puede considerar que el valor obtenido es alto con relación a otras escorias.

\section{REACTIVIDAD DE LA ESCORIA DE ACERÍA}

Se ha observado que la escoria reacciona con agua. Las principales manifestaciones de esta reactividad son, de una parte, la adquisición de una cierta resistencia y, de otra, una expansión retardada.

En la tesis doctoral de L. Amaral (5) se observó que las pastas de escoria molidas a tamaño inferior a $0,6 \mathrm{~mm}$ con una relación agua/escoria de 0,22 en probetas cilíndricas de 20 × $50 \mathrm{~mm}$ presentan resistencias a 28 días de $5 \mathrm{MPa}$ y a 90 días de 10,8 $\mathrm{MPa}$.

El estudio de los productos de hidratación efectuados con microsonda electrónica y con microscopía electrónica de barrido identificó puntos de la superficie de nueva formación a 28 días, viéndose una incipiente formación de silicato de calcio hidratado $(\mathrm{CSH})$, con relación $\mathrm{Ca} / \mathrm{Si}$ variable de punto a punto. La presencia de CSH se estableció por microscopía electrónica de barrido a 28 días y se confirmó plenamente en muestras de 1 año de edad. Para el micro análisis se utilizó la tecnica EDAX. A un año la pasta contenía no sólo CSH sino también gran cantidad de cristales hexagonales 0 pseudo hexagonales de silicatos aluminocálcicos. También se observaron estructuras amorfas de calcio, aluminio, silicio, hierro y magnesio, cromo y manganeso en pequeña cantidad. Todo ello de nueva formación (fotografias 1, 2 y 3). magnesium determined by $X$ ray fluorescence and the presence or not of periclase $(\mathrm{MgO})$ detected by $X$ ray diffraction.

Magnesium can be present in form of crystals of clinoenstatite $\left(\mathrm{MgSiO}_{3}\right)$ and merwinite $\left(\mathrm{Ca} 3 \mathrm{Mg}\left(\mathrm{SiO}_{4}\right)_{2}\right)$, also as a component of the amorphous phase of the slag and finally as periclase. Periclase is instable in presence of water, generating brucite $\left(\mathrm{Mg}(\mathrm{OH})_{2}\right)$. Taking into account the chemical and mineralogical composition of the samples of slag studied, we can affirm that there is no relation between the content of magnesium and the certainty of detecting periclase by $X$ ray diffraction at such quantitative levels.

The semi quantitative analysis of the amorphous phase) was determined with the Fullprof program (Rodriguez-Carvajal, 1990) based on the Rietveld Method. In the analyzed sample we introduced a $20 \%$ of $\mathrm{SiO}_{2}$ as reference. The results is approximately 70\% of amorphous phase present.., as we can see in table 4. We can consider this value as high in relation with other slag. The obtained quantification is not an exact result because of the complexity of the studied matrix.

\section{REACTIVITY OF THE EAF-SLAG}

It has been observed that the 11 samples of slag react with water. As result of this reaction we have a new products that will increase the strength of the system with cement but we have also retarded expansion.

In the Doctoral Thesis of L. Amaral (5) was observed that pastes of grounded slag $(<0,6 \mathrm{~mm}))$ with a ratio water/slag $=0,22$ presented strengths of 5 and 10,8 $\mathrm{MPa}$ at 28 and 90 days in test cylinder of $20 \times 50 \mathrm{~mm}$.

For the study of hydration products SEM and EDAX were used. Ten points of the new surface formed were analyzed after 28 days and the incipient formation of $\mathrm{CSH}$ was observed. The ratio $\mathrm{Ca} / \mathrm{Si}$ changed for each different point of measurement. The one year old paste showed not only a well formed CSH agglomerations but great quantity of hexagonal or pseudo hexagonal crystals of calcium aluminosilicate. In the same paste new amorphous structures containing $\mathrm{Ca}, \mathrm{Al}, \mathrm{Si}, \mathrm{Fe}$ and small quantities of $\mathrm{Mg}, \mathrm{Cr}$ and $\mathrm{Mn}$ were observed (photos 1, 2 and 3). 

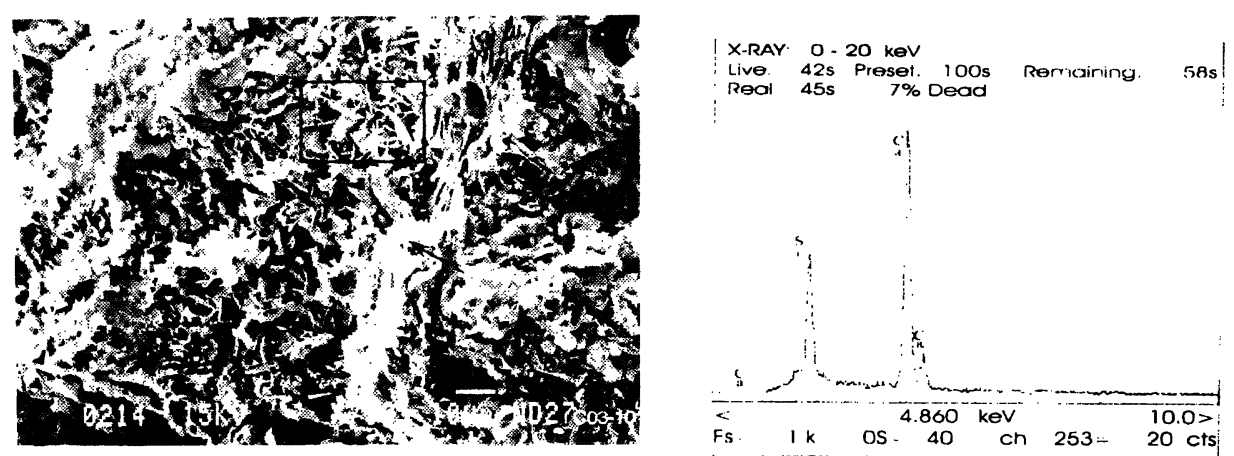

Foto 1.- Pasta de escoria, edad 1 año. Morfología CSH y análisis (5).

Photo I.- Slag paste, I year. CSH morphology and analysis (5).
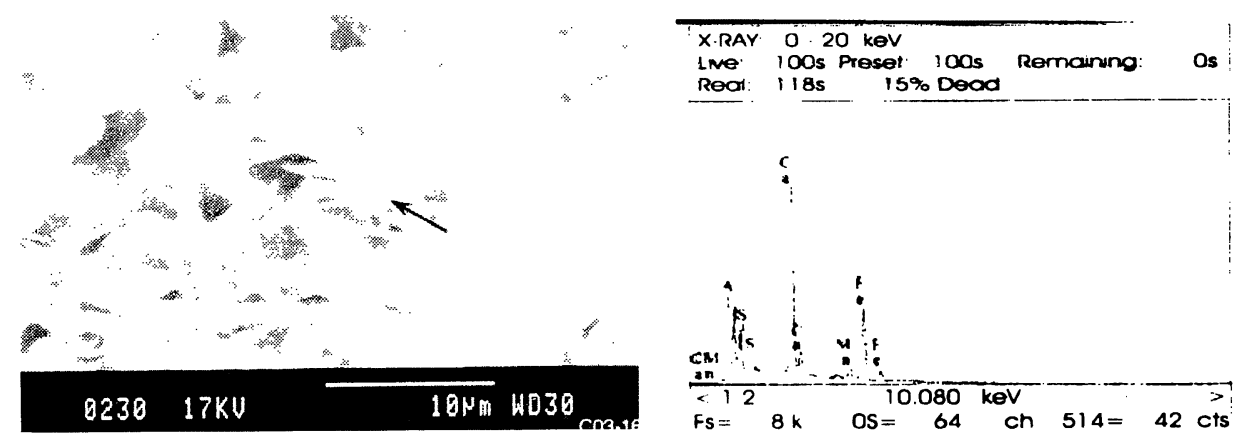

Foto 2.- Pasta de escoria, edad 1 año. Estructura amorfa y análisis (5).

Photo 2.- Slag paste, I year. Amorphous structure and analysis (5).
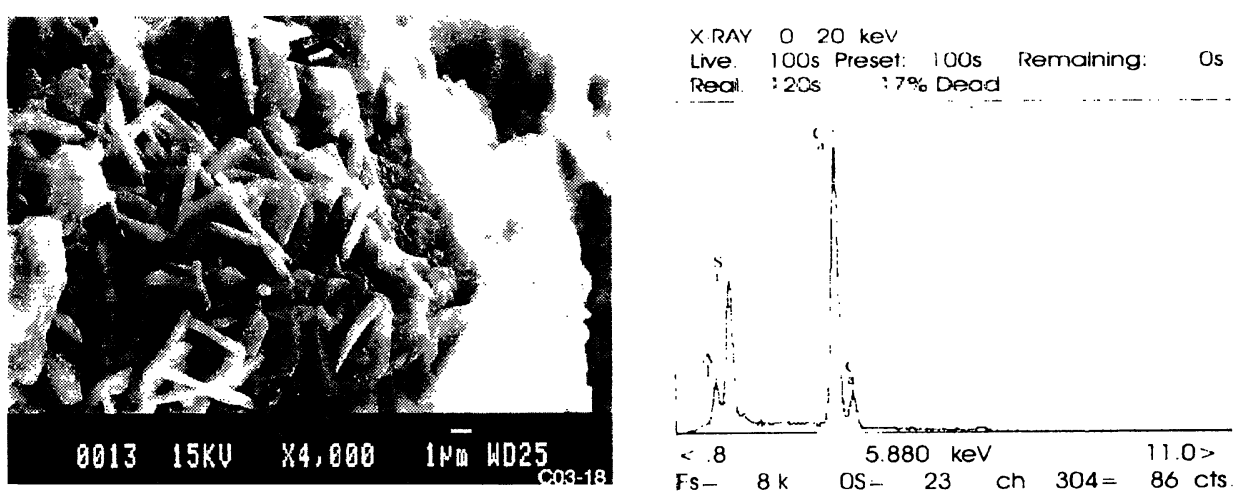

Foto 3.- Pasta de escoria, edad 1 año. Cristales hexagonales de silicatos aluminocálcicos y análisis (5).

Photo 3.- Slag paste, I year. Hexagonal crystal of calcium aluminosilicate and analysis (5).

El comité de normalización CEN/TC 154, al redactar la norma EN 1744-1(3) que incluye métodos para la determinación de la estabilidad volumétrica de la escoria cuando se utiliza como áridos, reconoce 3 tipos posibles de reacciones expansivas en las mismas: la hidratación de los compuestos de hierro, la transformación de la forma meta estable $\beta-\mathrm{C}_{2} \mathrm{~S}$ en la forma estable $\gamma-\mathrm{C}_{2} \mathrm{~S}$, más propia de las escorias de horno alto, y la hidratación de la cal libre y/o periclasa.
The CEN/TC 154 in the preparation of the standard UNE-EN 1744-1(3) consider three possible reactions as the cause of the retarded expansion of the steel slag when used as aggregates: the hydration of the ferrous compounds; The transformation of the not stable $\beta-C_{2} S$, more related with blast furnace slag, in the stable $\gamma-C_{2} S$; and the reaction of free $\mathrm{CaO}$ and periclase $(\mathrm{MgO})$ to form the hydroxides $\mathrm{Ca}(\mathrm{OH})_{2}$ and $\mathrm{Mg}(\mathrm{OH})_{2}$. To verify the importance of the first 
Para detectar los problemas relacionados con la primera causa se examina el comportamiento de 40 piezas de escoria entre 40 y $50 \mathrm{~mm}$, en agua durante dos días y se observa la posible fisuración. Si esta se presenta, se repite el ensayo con otras 30 piezas y si vuelve a aparecer la fisuración el árido se considera inestable. Nuestras escorias no sufrieron daño alguno.

El análisis de la segunda causa se efectúa viendo si un grano de escoria recién fisurado presenta fluorescencia sobre luz ultra violeta. Tampoco en este caso se registra ninguna actividad.

El fenómeno expansivo en nuestro caso parece concentrarse mayoritariamente en el $\mathrm{MgO}$, para el que se recomienda el llamado ensayo de vapor, aplicado durante 168 horas. Si la expansión resulta inferior al $5 \%$ y teniendo en cuenta que el ensayo es sobre una muestra no ligada y compactada hasta un volumen de huecos entre $20 \%$ y $25 \%$ el árido será suficientemente estable para su uso en capas de firme no ligado. En el caso de que la expansión sea $\leq 3,5 \%$, su uso podrá extenderse a las capas de rodaduras asfálticas (6). Nuestros áridos de escoria superan claramente este requisito y, por tanto, pueden considerarse aplicables a ambos casos.

Cuando los áridos de escoria de acero de arco eléctrico se encuentran ligados a una matriz más rígida, es preciso revisar la eficacia de los métodos convencionales de medida de expansión aplicados a tales condiciones y, en su caso, estudiar nuevas metodologías.

\section{ANÁLISIS DE LOS MÉTODOS CONVENCIONALES}

Para evaluar el comportamiento expansivo de las escorias hemos analizado el ensayo de Le Chatelier (1) y el ensayo de expansión en autoclave (2). Ambos ensayos, especificados para cementos, tienen por objeto detectar la importancia de la expansión de los óxidos de calcio y magnesio. El estudio de la expansión en autoclave efectuado se basó en la norma del ensayo citado, aplicándolo a la escoria como árido en una matriz de cemento. La modificación introducida en el ensayo de autoclave fue la sustitución de la pasta normal por un mortero de consistencia normal, cuya arena estaba compuesta por un $50 \%$ en volumen de "arena de escoria" (escoria machacada a tamaño $0-4 \mathrm{~mm}$ ) y $50 \%$ de arena normalizada.

En el ensayo de Le Chatelier ninguna de las 11 muestras ensayadas mostró carácter expansivo. Los hormigones reales obtenidos con escoria mostraron fenómenos expansivos. Por ello pensamos que las condiciones del reaction, the degradation of 40 pieces of slag $40-50 \mathrm{~mm}$ after 2 days immersion in water must be checked. If some fissures appear 30 new pieces of the same size must be tested. Only after determining the presence of fissures after the second immersion can we affirm the presence of this expansion mechanism. In our case no changes in the 11 samples were observed.

The $\beta-C_{2} S$ transformation is checked in the surface of a fresh new surface of a slag aggregate with ultraviolet radiation. In our samples did not register any activity.

In the slag tested the expansive activity is concentrated mostly in the $\mathrm{MgO}$ reaction. Following the UNE-EN 1744-1 the slag aggregates, compacted to a void content between 20 and $25 \%$, were submitted to the steam test. If the change in volume is $\leq 3,5 \%$ we can use it in asphalt layers (6). In our case no one of eleven samples studied reached this limit. So the CELSA EAFslag aggregates tested can be used in unbound layers respectively for asphalt layers.

When the EAF-slag aggregates are bounded in a cement matrix we need to check the efficacy of conventional tests applied to such conditions and to study new methodologies.

\section{ANALYSIS OF CONVENTIONAL METHODS}

To evaluate the expansive behavior of the slag in a cement matrix 2 different tests have been analyzed: Le Chatelier (1) and autoclave expansion (2). The two tests were initially specified for portland cement, and in the principle detect the expansive action of calcium and magnesium oxides. The autoclave test was applied to a mortar of normal consistency. The sand was composed of $50 \%$ in volume of slag and $50 \%$ of the standard natural sand. In the preparation of the slag sand the gravel and fine gravel were crushed and sieved.

In Le Chatelier test the potential expansive character of the 11 samples of slag, later detected in concrete, did not show up. We think that the conditions of Le Chatelier test are not suitable for creating sufficient 
ensayo de Le Chatelier no son adecuadas para crear una hidratación de los óxidos suficiente para producir cambios volumétricos, o porque asocia la lixiviación al proceso de hidratación acelerada. Estas hipótesis se reforzaron cuando, llevando el mismo tipo de probetas del ensayo de Le Chatelier al autoclave a $20 \mathrm{MPa}$, se consiguió una mayor formación de brucita y una notable expansión.

En el ensayo del autoclave con la modificación descrita, 3 de las 11 muestras que en los hormigones reales, en condiciones normales, habían mostrado expansión, no la presentaron (variación dimensional $<0,8 \%$ ). Los problemas están en que las dimensiones de los moldes limitan la dimensión máxima del árido a tamaño arena fina. La reducción del tamaño del árido lleva a la dispersión de los óxidos expansivos en la matriz de cemento y minimiza el efecto que se detectaría si el tamaño del árido fuera el de grava o gravilla. La composición adoptada $(50 \%$ de "arena de escoria") reduce también el efecto expansivo que tratamos de evaluar.

Se concluye que ninguno de los 2 ensayos analizados es válido para establecer un control de calidad de los áridos de escoria en cuanto a la estabilidad de los hormigones que pueden producirse con ellos.

\section{METODOLOGÍAS PROPUESTAS}

Las condiciones consideradas para definir los parámetros de nuevos ensayos fueron:

a) Acelerar las reacciones de hidratación de los óxidos de calcio y magnesio remanentes.

b) Mantener la temperatura y presión dentro de unos límites, que no produzcan cambios significativos ni en la microestructura, ni en las propiedades del hormigón. c) Ensayar los áridos de escoria dentro de una matriz rígida y densa. La baja porosidad de la matriz disminuye la capacidad de asimilar expansiones volumétricas y, por tanto, actúa amplificando los daños, con lo que facilita la identificación del problema.

\subsection{Características de las matrices rígidas ensayadas (hormigones)}

Partimos de un hormigón de referencia RC, cuyas características se presentan en la tabla 4. Para obtener los hormigones con escoria se han sustituido los áridos naturales por los de escoria en volumen, manteniendo constante la granulometría. Se produjeron 8 hormigones con los áridos de 7 muestras de escorias distintas. La nomenclatura y la resistencia de estos hormigones se dan en la tabla 5. Las características físicas de los áridos de escoria figuran en la tabla 6. La sustitución de árido natural por árido de escoria hydration of the oxides $o$ as to show the increase in volume or lixiviation is present. This was confirmed by autoclaving at $2 \mathrm{MPa}$ the same composition as in the Le Chatelier test and obtaining a large expansion and formation of brucita.

As the autoclave method with mortar, three of eleven samples showed non expansive character (dimensional variation $<0,8 \%$ ). The problems with this test are the dimensions of the moulds that limits the maximum dimension of the aggregates to very small sizes (fine sand). The reduction in the size of the aggregate leads to the dispersion of the expansive oxides in the cement matrix and minimises the effect that would be detected when aggregate in the size of gravel or coarse sand are used. The proportion adopted as to maintain the workability, also acts as factor which reduces the expansion effects.

It has therefore been conduced that none of the test methods mentioned are suitable for establishing the quality control of the slag aggregates for concrete regarding dimensional stability.

\section{PROPOSED METHODOLOGIES}

The conditions considered when defining the parameters of the new tests are:

a) To accelerate the hydration reactions of the remaining calcium and magnesium oxides.

b) To maintain the temperature and pressure conditions within limits not to produce significant damages in the microstructure nor in the properties of concrete.

c) To test the slag aggregates in a rigid and dense matrix, the low porosity.

\subsection{Characteristics of the rigid matrix (concrete)}

We started with a reference concrete $(R C)$ with conventional limestone aggregates whose characteristics are presented in table 4. In the production of slag concretes we started with a standard mixture $(R C)$ and one or more conventional aggregates have been substituted in volume for slag aggregate, maintaining the same grading. Eight concretes with seven different slags have been produced (table 5). The physical characteristics of EAF-slag aggregates are showing in table 6. 
TABLA $4 / T A B L E 4$

Caracteristicas del honnigon de referencia RC

(Characteristics of reference concrete $R C$ )

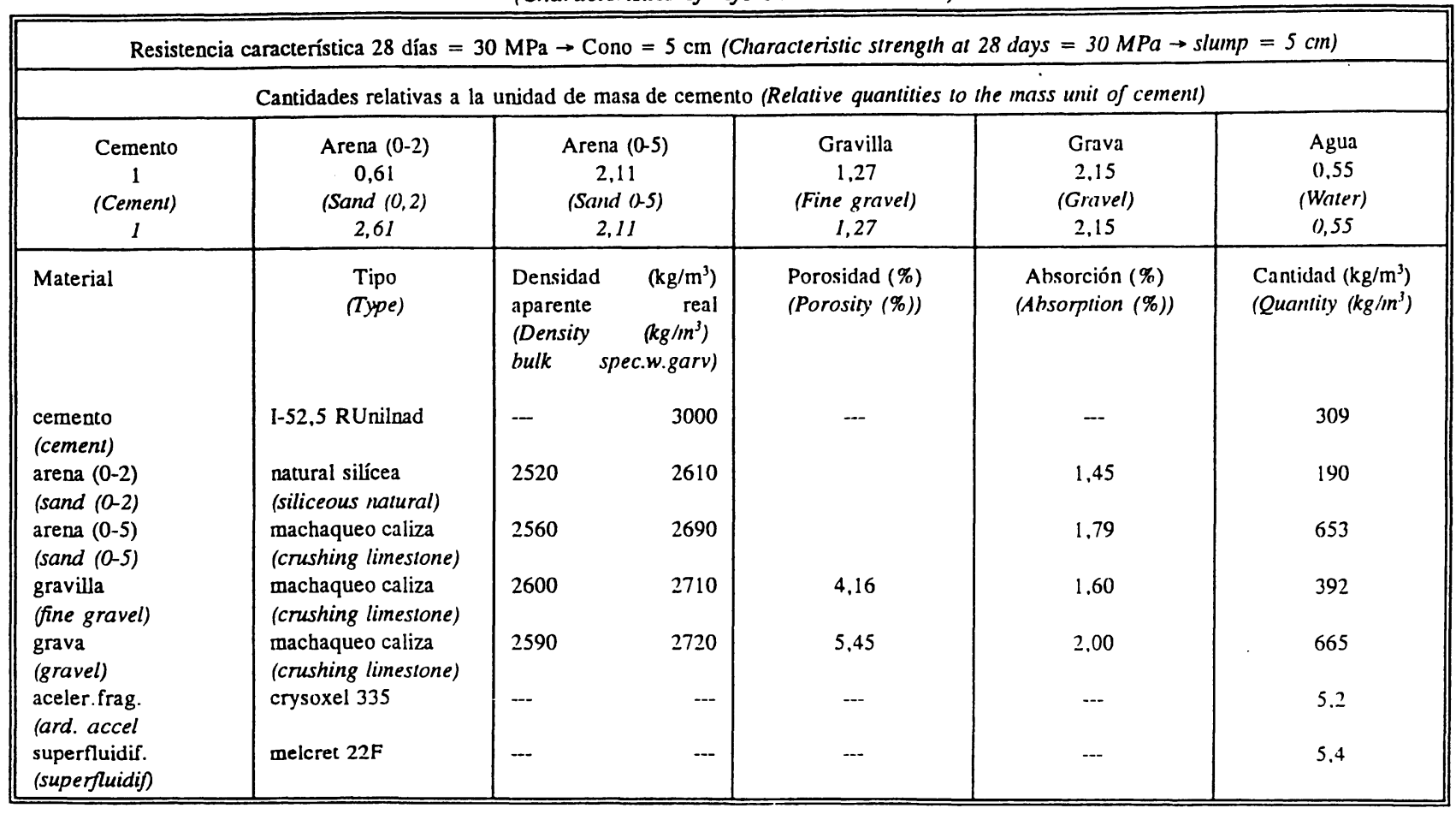

TABLA $5 / T A B L E 5$

Nomenclatura y propiedades de los hormigones con áridos de escoria de acería (Nomenclature and properties of slag concretes)

\begin{tabular}{|c|c|c|c|c|c|c|c|c|}
\hline $\begin{array}{l}\text { Hormigón } \\
\text { (Concrete) }\end{array}$ & $(0-2)$ & $(0-5)$ & $\begin{array}{c}\text { Gravilla } \\
\text { (Fine gravel) }\end{array}$ & $\begin{array}{c}\text { Grava } \\
\text { (Gravel) }\end{array}$ & $\begin{array}{l}\text { Escoria tipo } \\
\text { (Slag type) }\end{array}$ & $\begin{array}{l}\text { Sustitución } \\
\text { en vol. (\%) } \\
\text { (Agg. } \\
\text { substitution } \\
(\% \text { vol)) }\end{array}$ & $\begin{array}{l}\text { Cono }(\mathrm{cm}) \\
(\text { Slump }(\mathrm{cm}))\end{array}$ & $\begin{array}{c}\text { Resistencia } \\
\text { (MPa) } \\
\text { (Strength) } \\
(M P a))\end{array}$ \\
\hline $\mathrm{HEl}$ & \multirow{3}{*}{\multicolumn{2}{|c|}{$\begin{array}{l}\text { escoria (slag) } \\
\text { escoria (slag) } \\
\text { escoria (slag) }\end{array}$}} & escoria (slag) & escuria (slag) & 1 & 100 & 2 & +3.1 \\
\hline $\mathrm{HE} 4$ & & & escoria (slag) & escuria (slag) & 4 & 100 & 1.5 & +5.0 \\
\hline HE9 & & & escoria (slag) & escoria (slag) & 9 & 100 & 2 & 40.8 \\
\hline HGE 10 & natural & $\begin{array}{r}\text { calizo } \\
\text { (limestone) }\end{array}$ & $\begin{array}{c}\text { calizo } \\
\text { (limestone) }\end{array}$ & $\begin{array}{l}\text { escoria } \\
\text { (slag) }\end{array}$ & 10 & 35 & 3 & 38.2 \\
\hline $\mathrm{HgE} 11$ & natural & $\begin{array}{r}\text { calizo } \\
\text { (limestone) }\end{array}$ & $\begin{array}{c}\text { escoria } \\
\text { (slag) }\end{array}$ & $\begin{array}{c}\text { calizo } \\
\text { (limestone) }\end{array}$ & 11 & 20 & 3 & 35.0 \\
\hline HaE6 & natural & $\begin{array}{r}\text { escoria } \\
\text { (slag) }\end{array}$ & $\begin{array}{c}\text { calizo } \\
\text { (limesione) }\end{array}$ & $\begin{array}{c}\text { calizo } \\
\text { (limestone) }\end{array}$ & 6 & 35 & 1 & 35.3 \\
\hline HGE2 & natural & $\begin{array}{r}\text { calizo } \\
\text { (limestone) }\end{array}$ & $\begin{array}{c}\text { calizo } \\
\text { (limestone) }\end{array}$ & $\begin{array}{c}\text { escoria } \\
\text { (slag) }\end{array}$ & 2 & 35 & 2 & 33.9 \\
\hline HgE2 & natural & $\begin{array}{r}\text { calizo } \\
\text { (limestone) }\end{array}$ & $\begin{array}{c}\text { escoria } \\
\text { (slag) }\end{array}$ & $\begin{array}{c}\text { calizo } \\
\text { (limestone) }\end{array}$ & 2 & 20 & 3 & 32.8 \\
\hline
\end{tabular}

TABLA $6 /$ TABLE 6

Caracteristicas fisicas de los aridos de escoria

(Physical characteristics of EAF-slag aggregates)

\begin{tabular}{|c|c|c|c|c|c|c|c|c|c|c|}
\hline \multicolumn{11}{|c|}{ Escorias (Slag type) } \\
\hline Tamaño (Size) & $\begin{array}{c}1 \\
\text { arena } \\
\text { (sand) }\end{array}$ & $\begin{array}{c}1 \\
(G-g)\end{array}$ & $\stackrel{2}{G-g}$ & $\begin{array}{c}4 \\
\text { arena } \\
\text { (sand) }\end{array}$ & $G^{4}-g$ & $\begin{array}{c}6 \\
\text { arena } \\
\text { (sand) }\end{array}$ & $\begin{array}{c}9 \\
\text { arena } \\
\text { (sand) }\end{array}$ & $\begin{array}{c}9 \\
G-g\end{array}$ & $\begin{array}{l}10 \\
G\end{array}$ & $\begin{array}{l}11 \\
g\end{array}$ \\
\hline $\begin{array}{c}\text { Densidad aparente } \\
\text { (Bulk density) } \\
\left.\text { (kg/m }{ }^{3}\right)\end{array}$ & 3180 & 3580 & 3660 & 3170 & 3610 & 3120 & 3090 & 3560 & 3530 & 3510 \\
\hline $\begin{array}{c}\text { Densidad Real } \\
\text { (App.spc.density) } \\
\left(\mathrm{kg} / \mathrm{m}^{3}\right)\end{array}$ & 3590 & 3710 & 3860 & 3580 & 3740 & 3480 & 3410 & 3690 & 3670 & 3710 \\
\hline $\begin{array}{l}\text { Absorción (\%) } \\
\text { (Absorption (\%)) }\end{array}$ & 3.59 & 1,10 & 1,43 & 3,53 & 1,70 & 3,29 & 3,13 & 1.41 & 1.13 & 1.52 \\
\hline
\end{tabular}

$\mathbf{G}=$ grava (gravel) $\quad \mathrm{g}=$ gravilla (fine gravel) 
conlleva un aumento de la resistencia a compresión y a un ligero descenso de la trabajabilidad de los hormigones. La resistencia a compresión se ha determinado en probetas cúbicas de lado igual a $10 \mathrm{~cm}$, que también han sido utilizadas en los ensayos de expansión.

\subsection{Condiciones de ensayo}

Humedad Relativa(HR) y Temperatura(T)

-Ensayo referencia - Probetas en cámara húmeda a $\mathrm{HR} \geq 29 \%$ y $\mathrm{T}=20 \pm 2{ }^{\circ} \mathrm{C}$

-Ensayo en cámara climática - Probetas sometidas a $\mathrm{HR}=90 \pm 1 \%$ y $\mathrm{T}=70 \pm 1{ }^{\circ} \mathrm{C}$

-Ensayo en autoclave - Probetas sometidas a la acción del autoclave a $0,2 \mathrm{MPa}$ de presión y $\mathrm{T}=132^{\circ} \mathrm{C}$ durante 4,8 y 24 horas respectivamente.

Grupo de tres probetas de cada uno de los hormigones, $\mathrm{RC}, \mathrm{HE}_{1}, \mathrm{HE}_{4}, \mathrm{HE}_{9}, \mathrm{HGE}_{10}, \mathrm{HgE}_{11}, \mathrm{HaE}_{6}, \mathrm{HGE}_{2}, \mathrm{GhE}_{2}$, tras un curado de 2 meses en cámara húmeda se sometieron a las condiciones indicadas.

En las tres situaciones se midieron los cambios dimensionales, las variaciones de peso y se efectuó la inspección visual de posibles fisuras, roturas 0 desconchamientos superficiales en cada probeta.

\subsection{Resultados}

\section{Variaciones dimensionales}

Las variaciones dimensionales, tabla 7, presentan valores negativos en las tres condiciones, incluido el
We can observe that the substitution of natural aggregates by EAF-slag aggregates represents an increase in strength and decrease in workability of the concretes. The compressive strength was determined in cubic specimens $(10 \times 10 \times 10 \mathrm{~cm})$. The same kind of specimen were used in the expansion tests.

\subsection{Test conditions}

\section{Relative Humidity (RH and Temperature (T)}

-Reference test - Natural ageing in a curing room, $R H \geq 95 \%$ y $T=20 \pm 2{ }^{\circ} \mathrm{C}$.

-Climatic chamber test - Accelerated ageing, $R H=$ $90 \pm 1 \%$ and $T=70 \pm 1{ }^{\circ} \mathrm{C}$.

-Autoclave test - Accelerated ageing, 0,2 MPA, T=132

${ }^{\circ} \mathrm{C}$ during 4, 8 and 24 hours.

The tests started after the curing in a moist room (2 months). In each one of the three ageing conditions, three specimens type $R C$ (reference concrete) and $H E_{1}, H E_{4}, H E_{g}$, $H G E_{10}, H g E_{11}, H a E_{6}, H G E_{2}, H g E_{2}$ (slag concrete) are tested.

After each test dimensional variations, weight variations and visual inspection of possible cracks, failures or pop outs in the specimen were registered.

\subsection{Results}

\section{Dimensional variations}

The dimensional variations (table 7) showed negative values for all specimens submitted to one of the three

TABLA $7 / T A B L E 7$

Variaciones dimensionales y de masa de los honnigones (Dimensional and weight variation)

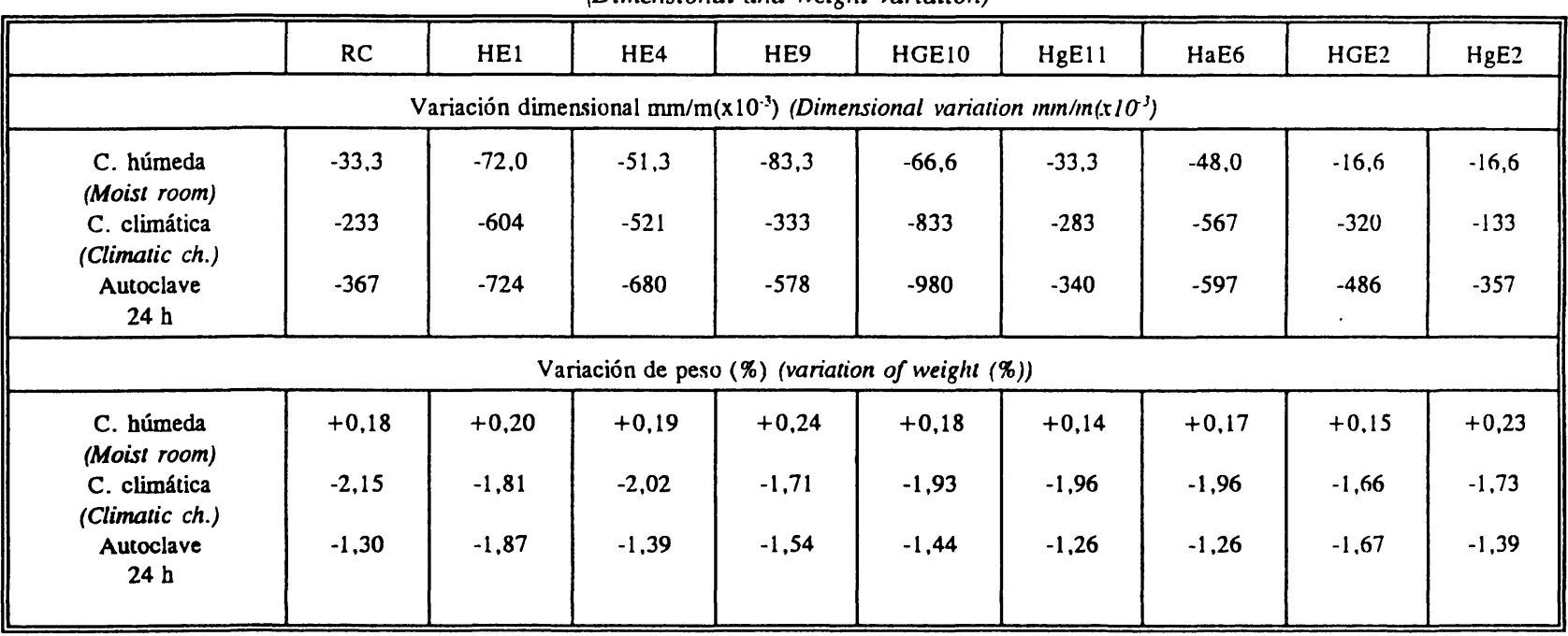


hormigón de referencia, sin embargo, el valor de la retracción es siempre mayor en las probetas con ácido de escoria. Los hormigones sometidos a las condiciones muestran retracciones 10 veces superior a las obtenidas con las probetas en cámara húmeda. La pérdida de agua causada por las condiciones de la cámara climática han contribuido fuertemente a esta retracción. En un trabajo posterior, R. Tejada (7), sobre el efecto del curado en cámara climática confirmó claramente la mayor retracción de los hormigones con escoria.

Las variaciones dimensionales no arrojan ninguna luz sobre la cuestión pues el fenómeno expansivo es puntual y asociado a áridos de escoria puntuales, pudiendo perfectamente presentarse valores negativos de variación dimensional global (posible retracción) asociado a estallidos expansivos locales.

\section{Variaciones de peso}

En cuanto a las variaciones de peso en \% tomadas tras 2 meses en cámara húmeda y en cámara climática respectivamente y las 24 horas de autoclave las tenemos reflejadas en la tabla 7. En las probetas de cámara húmeda se observa un ligero aumento de peso, que no permite diferenciar el hormigón de referencia del de escoria. En las de cámara climática se observa una disminución de peso que alcanza, como máximo, el $2 \%$ del peso de las probetas y que representa una pérdida de agua libre entre $35 \%$ y $40 \%$, respecto al inicio del proceso acelerado, no existiendo tampoco diferencia significativa entre el hormigón de referencia y los de escoria. En el ensayo en autoclave las probetas también sufren una pérdida de agua similar a la registrada en la cámara climática.

\section{Observaciones visuales}

Las observaciones visuales fueron concluyentes. Los daños que se presentan en las distintas condiciones fueron del mismo tipo. Se caracterizan por ser puntuales y siempre asociados a un grano de escoria. Se presentan desconchamientos, que ocasionan pérdida de material, produciendo un cráter, o la pérdida de una arista. Estos desconchamientos empiezan siempre por una fisura superficial. En el fondo del cráter siempre se presenta una sustancia polvorienta blanca o amarillenta, que se identifica por DRX como brucita, con algo de periclasa.

En las probetas en cámara húmeda los daños empezaron a aparecer a los 11 meses (fotografia 4a).

En las probetas en cámara climática que contenían escoria los primeros daños aparecieron a las 2 semanas (foto $4 b$ ). El efecto de la expansión fue más obvio en conditions, but the shrinkage values are in all cases greater in the specimen that contained EAF-slag aggregates. The concrete submitted to climatic chamber conditions showed shrinkage values 10 times greater as the concrete in moist room taken as reference. The loss of water caused by the temperature and moisture conditions of the climatic chamber have strongly contributed to the shrinkage. In a further study of the effect of steam curing in climatic chamber R.Tejada (7) observed the greater shrinkage of the EAF-slag concretes too.

The dimensional variations are inadequate to detect the expansive phenomena, because the expansion are associated only with the single grains of EAFslag aggregates and can coexist with negative values of the global dimensional variation.

\section{Variations in weight}

The table 7 presents the variations in weight in \% considered after 2 months of moist room curing, climatic chamber and 24 hours in autoclave respectively. In moist room cured specimen we observed a small increase in weight with any differences between the AEF-slag concretes and reference concrete. In the specimen tested in climatic chamber we observed a maximal decrease in weight of $2 \%$ that represents a $35-40 \%$ of the free water existing before start test. The specimen in autoclave experimented a lost in water of the same order.

\section{Visual control}

The visual observations are conclusive. The failures shown in the specimens submitted to the three tests are of the same type. Failures are localized and associated with a grain of EAF-slag. Pop outs produced loss of material, crater form holes or loss of edges. The pop outs started with surface crack. In the bottom of the crater holes we observed always a white or yellowish powder, that was identified by $X R D$ as brucite with small quantities of periclase.

In the specimen in moist room the failures started after 11 months (photo 4a).

In the specimen tested in climatic chamber the failures started after 2 weeks (photo 4b). 
los hormigones $\mathrm{HE}_{1}, \mathrm{HE}_{4}, \mathrm{HE}_{9}$, en los cuales la sustitución de áridos convencionales por árido de escoria era total. Sin embargo, el tiempo necesario para mostrar daños fue aproximadamente el mismo para todos los hormigones con escoria, que las presentaron sin excepción.

En el autoclave a 4 horas las fisuras eran insignificantes, crecieron a 8 horas y a 24 horas eran concluyentes y presentes en todas las probetas de hormigón con escoria.
The effect of expansion is more obvious and pronounced when the substitution of aggregates is total $\left(H E_{1}, H E_{4}, H E_{g}\right)$. The time needed for to start the failures were the same in all EAF-slag concretes.

In specimen after 4 hours autoclave cracks were insignificant, but grow after 8 hours and after 24 hours were present in all the specimens tested.
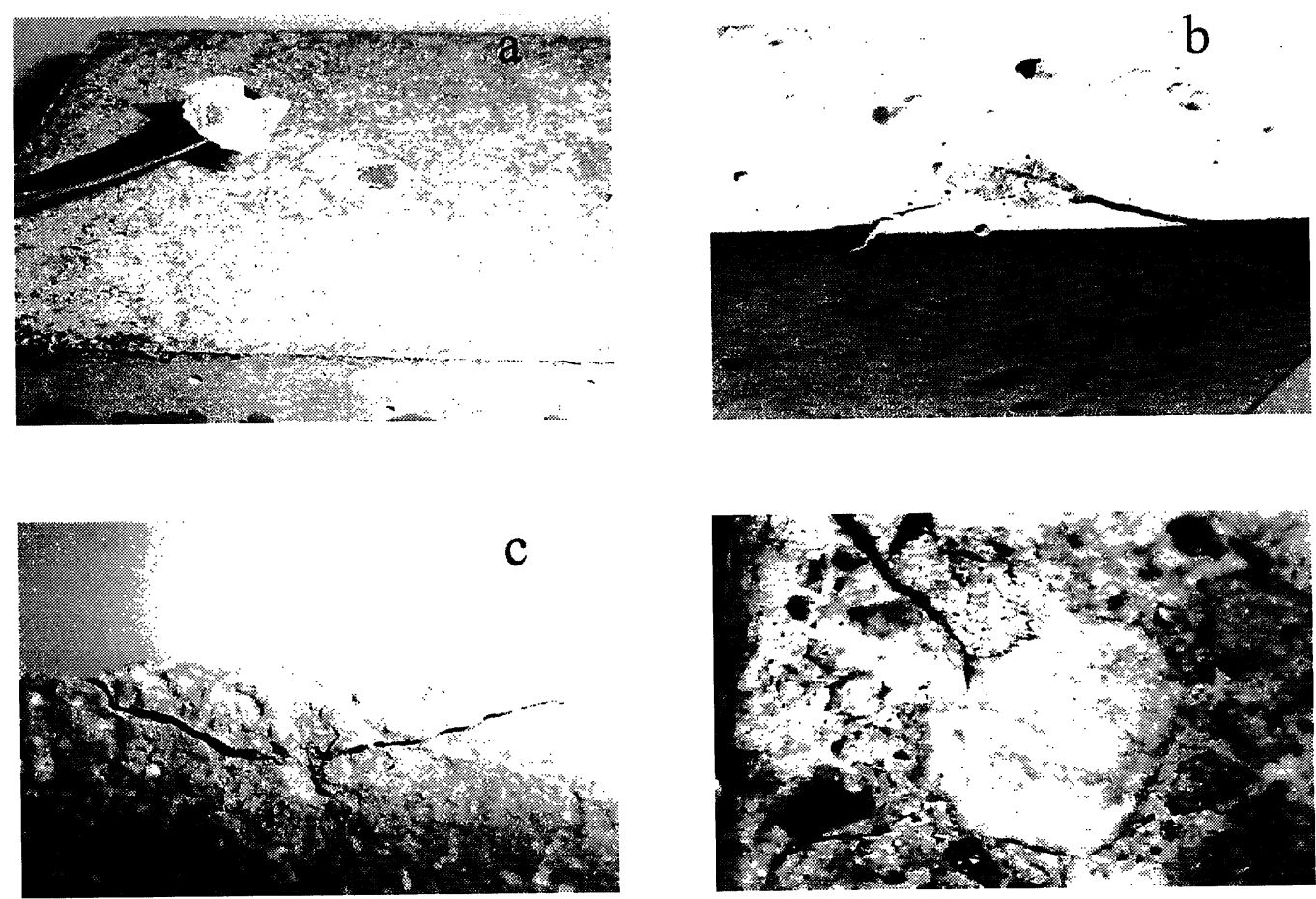

Foto 4.- a) Desconchamiento, cámara húmeda 11 meses. b) Rotura de arista, autoclave (24 h, 0,2 MPa). c) Rotura de arista, cámara climática 2 semanas. d) $\mathrm{MgO}$ y $\mathrm{Mg}(\mathrm{OH})_{2}$, cráter producido por expansión.

Photo 4.- a) Pop out, observed in moist room 11 months. b) Loos of edge, autoclave (24 h, 0,2 MPa). c) Loos of edge, climatic chamber 2 weeks. d) MgO y $\mathrm{Mg}(\mathrm{OH})_{2}$, crater produced by expansion.

\section{CONCLUSIONES}

-La escoria de acero de arco eléctrico es reactiva con el agua, mostrando un ligero poder ligante que se traduce en aumentos de resistencia

-Los hormigones con árido de escoria presentan sistemáticamente una retracción superior al hormigón de referencia que asociamos a la hidraulicidad de la escoria. A su vez, presenta expansión, puntual asociada con los granos de escoria y el $\mathrm{MgO}$ presente.

-La escoria de acero de arco eléctrico con contenidos de $\mathrm{MgO}$ alrededor del $5 \%$, tras ser sometida al ensayo

\section{CONCLUSIONS}

-EAF-slag reacts with water and shows a bonding effect that can produce increase of strength in concrete.

-EAF-slag concrete presents a higher shrinkage that we associate with the hydraulicity of slag. Expansions are localized and associated with the slag grains and $\mathrm{MgO}$.

$-E A F-$ slag with $M g O$ content $\leq 5 \%$ tested with the steam test can be used in unbounded layers and 
"steam test", muestra aptitud para su uso como material no ligado en capas del firme de carreteras y para capas de rodadura bituminosas. Este ensayo no es capaz de detectar el nivel de expansión que puede producir daños cuando la escoria se emplea en una matriz rígida.

-Los ensayos de Le Chatelier y del autoclave en las condiciones de las normas UNE 80-102-88 EN 196-3) y UNE 80-113-86 no pueden utilizarse en la determinación del potencial de expansión de la escoria utilizada como árido en el hormigón.

-En las probetas dejadas en cámara húmeda los daños comenzaron después de 11 meses.

-Sometiendo probetas de hormigón a las condiciones de $\mathrm{T}=70^{\circ} \mathrm{C}$ y $\mathrm{HR}=90 \%$ en cámara climática los daños provocados por los áridos de escoria se detectan a partir de 2 o 3 semanas.

-En el autoclave $(0,2 \mathrm{MPa})$ los daños se registran con claridad a las 24 horas y son de las mismas características que los observados en las probetas de la cámara climática.

-Sólo las observaciones visuales fueron concluyentes en cualquiera de las tres condiciones de ensayo que estuvieron sometidas las probetas.

-Todas las fisuras y escamaciones se asocian a la presencia del árido de escoria. Los hormigones con fracciones finas de escoria tendieron a producir mayor número de fisuras, pero de menores dimensiones de los que contenían las fracciones gruesas de la escoria.

-Las metodologías de ensayo propuestas tanto en cámara climática $\left(\mathrm{T}=70^{\circ} \mathrm{C}\right.$ y $\left.\mathrm{HR}=90 \%\right)$, como en autoclave a 0,2 MPa son válidas para detectar las expansiones generadas en las escorias de acería de arco eléctrico cuando se utilizan como áridos en matrices rígidas. bituminous mixtures. The steam test is not useful in detecting the potential of expansion of slag when used as aggregate in rigid matrix.

-Le Chatelier - UNE 80-102-88 (EN 196-3), and autoclave - UNE 80-113-86 can not be used in detecting the potential expansion of slag when used as aggregate in concrete.

-In the EAF-slag concrete specimen stored in moist room failures appeared after 11 months.

-In the climatic chamber at $70^{\circ} \mathrm{C}$ and $90 \% \mathrm{RH}$ the failures started after 2 or 3 weeks.

-In the autoclave $(0,2 \mathrm{MPa}, 24 \mathrm{~h})$ the failures were practically the same as observed in the specimens tested in climatic chamber.

-Only the visual control after the three conditions of test was conclusive.

-All failures, cracks and pop out are associated with the presence of EAF-slag aggregate. The concrete with fine EAF-slag aggrgate present more cracks, but the cracks are of smaller dimensions.

-The test methodologies proposed are valid to detect the expansion potential of EAF-slag aggregates when used in rigid matices.

\section{BIBLIOGRAFÍA}

(1) Asociación Española de Normalización y Certificación Métodos de ensayo de cementos. Determinación del tiempo de fraguado y de la estabilidad de volumen. UNE 80-102-88 (EN 196-3) Madrid (1988).

(2) Asociación Española de Normalización y Certificación Métodos de ensayo de cementos. Ensayos fisicos. Determinación de la expansión en autoclave UNE 80-113-86. Madrid (1986).

(3) Asociación Española de Normalización y Certificación. Ensayos para determinar las propiedades químicas de los áridos. Parte 1: Análisis químico UNE-EN 1744-1. Madrid (1999).

(4) Asociación Española de Normalización y Certificación. Métodos de ensayo de cementos. Análisis químico. Determinación del óxido de calcio libre; Método del etilenglicol. UNE 80-216-86. Madrid (1986).

(5) L. Amaral. Hormigones con escorias de horno eléctrico como áridos: Propiedades, durabilidad y comportamiento ambiental. Tesis doctoral dirigida por Enric Vàzquez, Universitat Politècnica de Catalunya, Barcelona (1999), pp. 97-114.

(6) H. Motz, J.Geiseler. Products of steel slags. An opportunity to save natural resources. Proc. Wascon 2000.. Elsevier Science Ltd. Oxford,U.K. (2000)pp. 207-220.

(7) R. Tejada. Estudio de la retracción y del curado acelerado utilizado en prefabricación de hormigones con escoria de acero como árido. Tesina de especialidad dirigida por Enric Vàzquez Universitat Politècnica de Catalunya, Barcelona (1999), pp. 53-56. 